\title{
Exploring nomological link between automated service quality, customer satisfaction and behavioural intentions with CRM performance indexing approach: Empirical evidence from Indian banking industry
}

\author{
Arup Kumar Baksi
}

Department of Management Science, Bengal Institute of Technology \& Management, Santiniketan, India

\begin{tabular}{|c|c|}
\hline A R T I C L E I N F O & A B S T RACT \\
\hline $\begin{array}{l}\text { Article history: } \\
\text { Received March 25, } 2012 \\
\text { Received in revised format } \\
17 \text { October } 2012 \\
\text { Accepted } 17 \text { October } 2012 \\
\text { Available online } \\
\text { October } 182012 \\
\text { Keywords: } \\
\text { Service quality } \\
\text { Automation, loyalty } \\
\text { Switch } \\
\text { Customer-relationship- } \\
\text { management } \\
\text { Nomological } \\
\text { Bank }\end{array}$ & $\begin{array}{l}\text { Automation in service delivery has increased the consumers' expectation with regard to service } \\
\text { quality and subsequently the perception of the same. Technology-driven services redefined } \\
\text { quality dimensions and their subsequent impact on the behavioural outcomes of the consumers } \\
\text { with specific reference to attitudinal loyalty and propensity to switch. Customer Relationship } \\
\text { Management (CRM) has further reinforced the operational aspects of a service provider by } \\
\text { integrating the behavioural perspectives with technology. This paper attempts to explore the } \\
\text { nomological link between automated service quality and its behavioural consequences with } \\
\text { specific reference to consumers' attitudinal loyalty and their intention to switch or defect from } \\
\text { their present service provider. The study further takes into consideration the moderating effects } \\
\text { of the performance of the dimensions and attributes of customer relationship management by } \\
\text { introducing a novel approach to CRM performance indexing. The cross-sectional study was } \\
\text { carried out with the customers of State Bank of India at Asansol, Durgapur, Bolpur and } \\
\text { Santiniketan in West Bengal, India. The study used structural equation modeling (SEM) to } \\
\text { assess and validate the nomological relationship between the variables. }\end{array}$ \\
\hline
\end{tabular}

(C) 2013 Growing Science Ltd. All rights reserved.

\section{Introduction}

The banking operation in India has undergone a total transformation with the introduction of technology. The conventional unidimensional service market trinity got converted to a three dimensional interactive model with service providers (banks), service employees (bankers) and customers interacting with each other through technology. The knowledge, skill and behaviour of service employees, considered as internal customers, remained critical while perceiving service quality, although automated banking services ensured disintermediation to a large extent (Khan and Mahapatra, 2009). Conventional service quality concept has also metamorphosed with operational efficiency, security and confidentiality of information stored, reliability, accuracy and speed of

* Corresponding author. Tel: +919/918/917/914/913 2533 - (0342)

E-mail addresses: baksi.arup@gmail.com (A. K. Baksi) 
transactions, virtual interfaces, IVR etc. being considered as major quality dimensions. Customers are demanding new level of convenience and flexibility in addition to powerful and easy-to-use financial management tools, products and services that conventional banking operations could not offer (Hanzaee and Sadeghi, 2010). Studies conducted by Ravi et al (2007) revealed that automated banking transactions in India is still at its nascent stage with private sector banking responding and adapting earlier to these changes (Malhotra and Singh, 2007). It was only in the extreme later half of 1990s that the nationalized public sector banks in India decided to shade-off its silos-based operational legacy and upgrade themselves to the digital platform. This shift of paradigm was further stimulated by the recommendations of Rangarajan committee to initiate automation in banking operations.

The IT Act of 2000 of Govt. of India provided a legal recognition to electronic banking transactions with RBI establishing a work-group to supervise and monitor issues such as security and technology, legal and control and supervision. Automated banking, for a considerable period of time, was an activity constrained to the metros and big cities in India. Phenomenal penetration of technologies and its convergence paved the path for banking service automation in semi-urban and rural areas of India also. The probable two behavioural consequences of service quality which are factor-prime for service organizations like banks are customer loyalty and propensity to switch because both these phenomenon are linked to profitability. With the competition becoming fierce, customer loyalty and favourable behavioural consequences have emerged as two potential defensive tools for the banks. The recent adoption of Customer Relationship Management (CRM) as a business philosophy saw the banks developing better proactive strategies to ensure better personalization and customization of service delivery.

This paper attempts to explore the probable impacts of automated service quality on behavioural intentions of customers in a CRM dominated environment of a bank. The rationale behind choosing SBI has been the completion of their decade long modernization and up-scaling of their operation from a legacy dominated silos-based customer transaction to a electronic banking format and being the largest nationalized bank in India its geographical penetration and bank branch networking (availability of services). The organisation of this study following the 'Introduction' has been done as: review of literature, research model and formulation of hypotheses, methodology, data analysis and interpretation and conclusion with limitations of the study and future research prospect.

\section{Review of literature}

Over the last three decades or so service quality has emerged as one of the most critical areas to focus upon for the academic researchers, managers and practitioners as a result of its phenomenal impact on customer satisfaction, customer retention, lowering of costs, profitability and overall sustainable business performance (Peng \& Wang, 2006; Leonard \& Sasser, 1982; Gammie, 1992; Hallowell, 1996; Chang \& Chen, 1998; Lasser et al., 2000; Silvestro \& Cross, 2000, Sureshchander et al., 2002, Guru, 2003; etc.). Researchers, over the years, explored and conducted a number of empirical works to understand the nature of service quality, its dimensions and dynamics and probable ways to enhance the perceived service quality (Cronin \& Taylor, 1992, 1994; Rust \& Zahorick, 1993; Avkiran, 1994, Kearns \& Nadler, 1992; Parasuraman et al., 1985, 1988, Julian \& Ramaseshan, 1994, Llosa et al., 1998, Crosby \& Stephens, 1987). The study of service quality was pioneered by Parasuraman, Zeithaml and Berry (PZB), who developed the gaps framework in 1985 and its related SERVQUAL instrument (Parasuraman et al., 1985, 1988, 1991) whereby five dimensions of service quality were proposed namely tangibles, reliability, responsiveness, assurance and empathy. The transition of service delivery system from employee-customer interaction to employee-technology and technology-customer interactions included a new dimension in service delivery mechanism and vis-à-vis perceived service quality (Alkibsi \& Lind, 2011). 
Henderson et al. (2003) was of the opinion that automated service provides organisation to introduce new models for service design and development. Ruyter et al. (2001) defined automated service as interactive, content-centered and internet-based customer service driven by the customer and integrated with the related organisation customer support process and technologies with the goal of strengthening the customer-service provider relationship. Parasuraman et al. (2005) viewed automated services as web-based services while Buckley (2003) conceptualized automated services as electronic provision of services to a customer. Automated service quality has been identified by Santos (2003) as consumers' evaluation of e-service quality in a virtual market place.

Introduction of automated banking services triggered changes in consumer behaviour, consumer perception towards banking service quality, innovation in service delivery system, channel integration, communication and relationship marketing which received adequate emphasis on behalf of the academic researchers (Laforet \& Li, 2005; Gerard \& Cunningham, 2003; Hernandez \& Mazzon, 2007; Wolfinbarger \& Gilly, 2002; Yang et al., 2004, Mukherjee \& Nath, 2003; Baksi, 2012). Banking, which was conventionally a high contact service, the disintermediation with the introduction on technology, was considered to be critical towards establishing quality perception in the minds of the customers (Broderick \& Vachirapornpuk, 2002).

Dhabolkar ((1994) argued that the automated channels made customer participation in service delivery process more intense. A number of researchers considered ATM, internet banking, telephone/mobile banking as the principal automated service delivery channels (Dabholkar, 1994; Meuter et al., 2000; Szymanski \& Hsiech, 2006; Radecki et al., 1997). Quite a few researchers explored automated service quality dimensions and subsequently developed models to assess service quality such as SITEQUAL (Yu \& Donthu, 2001), WEBQUAL (Loiacono et al., 2002), eTailQ (Wolfinbarger \& Gilly, 2002), E-SERVQUAL (Zeithaml et al., 2005) SSTQUAL (Lin \& Hsiech, 2006). Al Hawari et al. (2005) developed the concept of Automated Service Quality Index (ASQI) by highlighting five factors - ATM service quality, telephone banking, internet banking services, core service quality and customer perception of service quality. Table 2 summarizes the review of the dimensions of automated service quality.

Superior service quality leads to favorable behavioral intentions, leading to retention and subsequent generation of revenue, increased spending, payment of price premiums, and generation of referred customers (Zeithaml et al., 1996). Excellent service is a profit strategy because the results include new customers, increased business with existing customers, fewer lost customers, more cushioning from price competition and fewer mistakes requiring the services to be repeated (Berry et al., 1994). Listening to the customer is a part of providing excellent service. Inferior service quality leads to unfavorable behavioral intentions, which lead to customer defection from the organization, which leads to decreased spending, lost customers, and increasing costs associated with attracting new customers (Zeithaml et al., 1996). Customer switching behavior can damage market share and profitability. Switching can cost an organization the customer's future revenue stream (Keaveney, 1995). Evidence that customer loyalty makes an organization more profitable makes it imperative that complaints and other unfavorable behavioral intentions are handled effectively to ensure the stability of these relationships (Tax \& Brown 1998a). Managers of service firms should know that some customers would switch services even when they are satisfied with a former provider (Keaveney, 1995). Zeithaml et al. (1996) highlighted the behavioural consequences of service quality and proposed a comprehensive, multi-dimensional framework of customer behavioural intentions, nomenclated as Behavioural Intentions Battery (BIB), to be used in the service industry. The framework consists of 13-items across five dimensions namely loyalty to organisation, propensity to switch, willingness to pay more, external responses to a problem and internal responses to a problem (Baksi \& Parida, 2011). Yang and Fang (2004) examined the influence of dimensional differences on 
online service satisfaction and dissatisfaction. Yen (2005) was of the opinion that technology readiness is one of the major determinants of customer satisfaction for online services.

Table 2

Summarized reviews of automated service quality dimensions

\begin{tabular}{|c|c|c|c|}
\hline Contributor & Year & Dimensions & Context \\
\hline Dabholkar & 1996 & website design, reliability, delivery, ease-of-use, enjoyment and control & e-services \\
\hline Zeithaml et al. & 2000 & efficiency, reliability, fulfillment, privacy, responsiveness, compensation and contact & $\begin{array}{l}\text { Online retail } \\
\text { services }\end{array}$ \\
\hline Yoo \& Donthu & 2001 & ease of use, aesthetic design, processing speed and interactive responsiveness & $\begin{array}{l}\text { Online retail } \\
\text { services }\end{array}$ \\
\hline Cox \& Dale & 2001 & $\begin{array}{l}\text { website appearance, communication, accessibility, credibility, understanding and } \\
\text { availability }\end{array}$ & $\begin{array}{l}\text { Online retail } \\
\text { services }\end{array}$ \\
\hline Jun \& Cai & 2001 & website design, information, ease of use, access, courtesy, responsiveness and reliability & $\begin{array}{l}\text { Online banking } \\
\text { services }\end{array}$ \\
\hline Yang & 2001 & website design, security and information & $\begin{array}{l}\text { Online retail } \\
\text { services }\end{array}$ \\
\hline $\begin{array}{l}\text { Wolfinbarger \& } \\
\text { Gilly }\end{array}$ & 2002 & website design, reliability, security and customer service & $\begin{array}{l}\text { Online shopping } \\
\text { sites }\end{array}$ \\
\hline Zeithaml et al. & 2002 & Security, communication, reliability, responsiveness and delivery & e-services \\
\hline Madu \& Madu & 2002 & $\begin{array}{l}\text { Performance, features, structure, aesthetics, reliability, serviceability, security and } \\
\text { system integrity, trust, responsiveness, service differentiation and customization, web- } \\
\text { store police, reputation, assurance and empathy }\end{array}$ & e-services \\
\hline Loiacono et al. & 2002 & $\begin{array}{l}\text { informational-fit-to-task, interaction, trust, response-time, design, intuitiveness, visual } \\
\text { appeal, innovativeness, flow-emotional appeal, integrated business communication, } \\
\text { business processes and substitutability }\end{array}$ & $\begin{array}{l}\text { Online retail } \\
\text { services }\end{array}$ \\
\hline Yang \& Jun & 2002 & Website design, security, reliability, responsiveness, accessibility and customization & $\begin{array}{l}\text { Online retail } \\
\text { services }\end{array}$ \\
\hline Surjadaja et al. & 2003 & Security, interaction, responsiveness, information, reliability, delivery and customization & e-services \\
\hline Yang et al. & 2003 & $\begin{array}{l}\text { responsiveness, reliability, credibility, ease-of-use, convenience, communication, access, } \\
\text { competence, courtesy, personalization, collaboration, security and aesthetics }\end{array}$ & $\begin{array}{l}\text { Online retail } \\
\text { services }\end{array}$ \\
\hline Yang et al. & 2004 & responsiveness, reliability, ease-of-use, competence, security and product portfolio & $\begin{array}{l}\text { Online shopping } \\
\text { sites }\end{array}$ \\
\hline Field et al. & 2004 & Website design, reliability, security and customer service & e-services \\
\hline Kim \& Stoel & 2004 & $\begin{array}{l}\text { Web appearance, entertainment, information, transaction capability, responsiveness and } \\
\text { trust }\end{array}$ & $\begin{array}{l}\text { Online retail } \\
\text { services }\end{array}$ \\
\hline Yang \& Fang & 2004 & $\begin{array}{l}\text { Responsiveness, reliability, credibility, competence, access, courtesy, communication, } \\
\text { information, responsiveness and website design }\end{array}$ & e-services \\
\hline Gounaris et al. & 2005 & Website design, information, trust, responsiveness and reputation & $\begin{array}{l}\text { Online retail } \\
\text { services }\end{array}$ \\
\hline $\begin{array}{l}\text { Parasuraman et } \\
\text { al. }\end{array}$ & 2005 & Efficiency, availability, fulfillment, privacy, responsiveness, compensation and contact & e-services \\
\hline Lee \& Lin & 2005 & Website design, reliability, responsiveness, trust and personalization & $\begin{array}{l}\text { Online retail } \\
\text { services }\end{array}$ \\
\hline Kim et al. & 2006 & $\begin{array}{l}\text { Efficiency, system availability, fulfillment, privacy, responsiveness, compensation, } \\
\text { contact and graphic style }\end{array}$ & \\
\hline $\begin{array}{l}\text { Fassnacht \& } \\
\text { Koese }\end{array}$ & 2006 & $\begin{array}{l}\text { Graphic quality, layout, attractiveness of selection, information, ease of use, technical } \\
\text { quality, reliability, functional benefit and emotional benefit }\end{array}$ & e-services \\
\hline Cristobal et al & 2007 & Website design, customer service, assurance and order management & e-services \\
\hline $\begin{array}{l}\text { Sohn \& } \\
\text { Tadisina }\end{array}$ & 2008 & $\begin{array}{l}\text { Trust, speed of delivery, reliability, ease-of-use, customized communication, website } \\
\text { content and functionality }\end{array}$ & $\begin{array}{l}\text { Online financial } \\
\text { services }\end{array}$ \\
\hline Li et al. & 2009 & $\begin{array}{l}\text { Website design, reliability, responsiveness, security, fulfillment, personalization, } \\
\text { information and empathy }\end{array}$ & e-services \\
\hline
\end{tabular}

The automation of bank's operational aspects was not restricted to technological upgradation alone as it paved way for a novel business philosophy - Customer Relationship Management (CRM). Customer Relationship Management (CRM), defined by Nguyen et al (2007), is an information system that enables organizations to track customers' interactions with their firms and allows employees to extract customer-based information namely history of sales, unresolved problems, payment records, service records etc. Customer Relationship Management (CRM) has been argued to replace the traditional 4Ps of marketing (product, price, place and promotion) concept as a dominant logic in marketing process (Guraú, 2003) and refers to all business activities directed towards initiating, establishing, maintaining, and developing successful long-term relational exchanges (Heide, 1994; Reinartz \& Kumar, 2003). Gradual polarization of marketing process towards a 
relationship base was found to be dyadically more effective in establishing mutually profit-benefit transactions between sellers and buyers respectively. The scholastic debate sprung a number of views about the domain of CRM - some researchers view CRM as a mere software based application, therefore emphasizing on the process part; while others consider CRM as a philosophy which aims to translate customer intimacy into profit (Yueh et al, 2010, Soon, 2007; Nguyen et al, 2007 \& Eric et al, 2006). Subsequent research works have highlighted CRM as an integration of people, process and technology, targeted to bring firms closer to customers. Empirical research works pointed out, time and again, towards the mutual and symbiotic benefits both for the sellers and customers (Dekimpe, Steenkamp, Mellens \& Abeele, 1997). In a study Paul Gray and Jongbok Byun (2001) viewed CRM as a continuous flow of corporate changes in culture and processes that combines three focal areas: (i) Customer (ii) Relationship and (iii) Management. With this introduction of hyper-customized products and services, particularly in the cross-selling and up-selling domains of a financial service organization, the customer needs and desires have undergone a sea change. One of the results of CRM is the promotion of customer loyalty (Evans \& Laskin, 1994), which is considered to be a relational phenomenon (Chow \& Holden, 1997; Jacoby \& Kyner, 1973; Sheth \& Parvatiyar, 1995; cited by Macintosh \& Lockshin, 1997). The benefits of customer loyalty to a provider of either services or products are numerous, and thus organizations are eager to secure as significant a loyal customer base as possible (Gefen, 2002; Reinartz \& Kumar, 2003; Rowley \& Dawes, 2000).

Review of literature revealed that while academic research works were carried out substantially to identify the dimensions of automated service quality, not much of emphasis was given to explore the probable linkage between perceived automated service quality and behavioural consequences of customers in a CRM dominated business environment. Further to this not much academic support has been fetched towards indexing CRM activities based on the performance of its components namely people, process and technologies and their subsequent variables.

\section{Constructs development of Customer Relationship Management Index (CRMI)}

Based on a novel approach by Baksi and Parida (2012) to develop a Multi-Channel Service Quality Index (MCSQI), a similar approach can be used to develop a Customer Relationship Management Index (CRMI) based on S-shaped logistic model:

$$
y=\frac{m}{1+e^{a+b t}}
$$

where $y$ is the benefit of the technology application at time $t, m$ is the upper bound on the benefits of the application, and $a$ and $b$ are constants that determine the shape of the curve. Similar kind of logic can be used in computing Customer Relationship Management Index (CRMI) whereby it is assumed that CRMI will improve with the improved performance of CRM components (CRMCP). The impact of CRMCP performance at time ' $t$ ' is proportional to the CRMI gained at time $t-1$ $\left(\mathrm{CRMI}_{\mathrm{t}-1}\right)$ relative to maximum possible gains from the CRMCP performance (i.e. 1) and the remaining CRMI is yet to be gained (i.e $1-\mathrm{CRMI}_{\mathrm{t}-1}$ ). It can be represented as (over time $t$ ):

$$
\frac{d C R M I}{d t}=-C R M C P\left(1-C R M I_{t-1}\right),
$$

where CRMCP is a term denoting efficiency of performance in delivering services for a service provider. Solving equation-1 for CRMI:

$$
C R M I=\frac{1}{1+e^{a+C R M C P_{t}}} .
$$


Eq. (2) represents a S-shaped logistic model where 1 is the upper-bound on the CRMI from the CRMCP performance. It is assumed that the constant ' $a$ ' is zero because each service provider is supposed to initiate CRM induced services with a negligible CRMI. Therefore equation for CRMI is developed as:

$$
C R M I=\frac{1}{1+e^{C R M C P_{t}}} .
$$

The term CRMCP is a function of the relative weight of the eigenvalue (RWE) of each CRM components multiplied by the average factor value (AVF) of the corresponding CRM component.

$$
C R M C P=R W E_{C R M C P 1} A V F_{C R M C P 1}+R W E_{C R M C P 2} A V F_{C R M C P 2}+R W E_{C R M C P} 3 A V F_{C R M C P 3}
$$

where CRMCP1 is People dimension, CRMCP2 represents Process dimension and CRMCP3 denotes Technology dimension.

\section{Research model and formulation of hypotheses}

Based on the review of literature this paper attempts empirically to explore possible linkages between perceived automated service quality (PASQ) and behavioural intentions (BI) for bank customers in a Customer Relationship Management (CRM) environment. The proposed research model is depicted in Fig. 1 below:

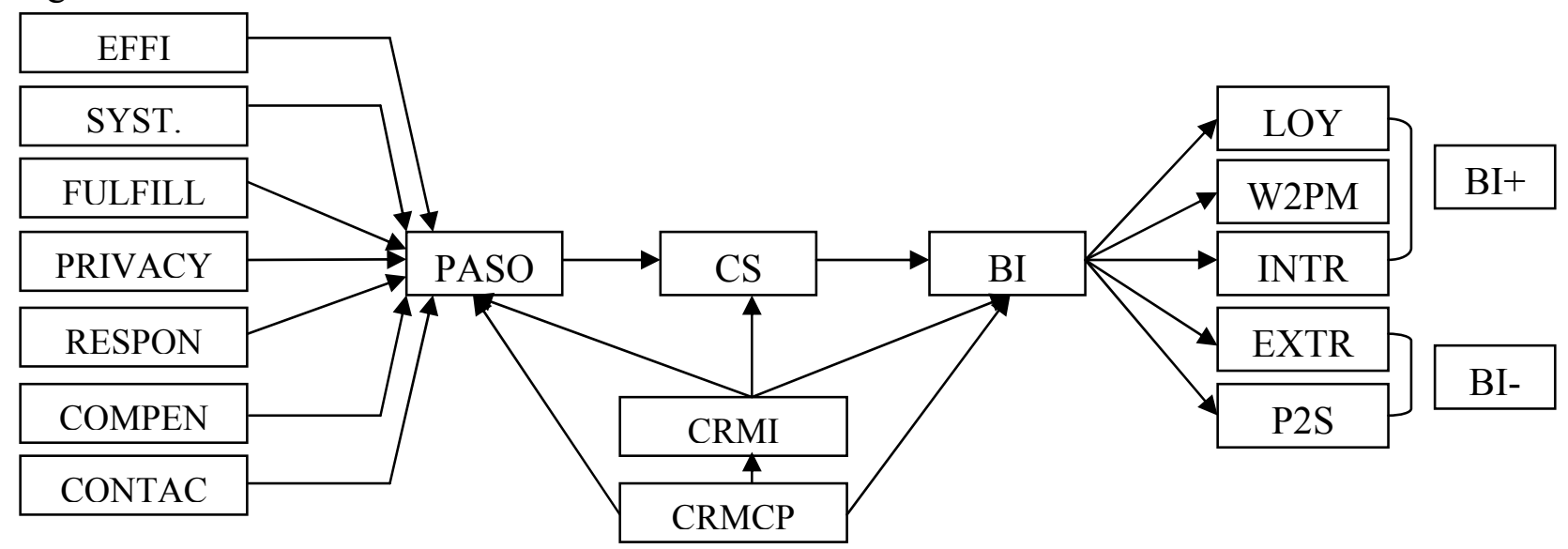

Fig. 1. The research model

Accordingly it is hypothesized that:

$\mathrm{H}_{1:}$ Customer satisfaction (CS) is influenced by perceived automated service quality (PASQ)

$\mathrm{H}_{01}$ : Customer satisfaction (CS) is uninfluenced by perceived automated service quality (PASQ)

$\mathrm{H}_{2}$ : Behavioural intentions (BI) are dependent on customer satisfaction (CS)

$\mathrm{H}_{02}$ : Behavioural intentions (BI) are independent on customer satisfaction (CS)

$\mathrm{H}_{3}$ : Performance of CRM components (CRMCP) influence CRM index (CRMI).

$\mathrm{H}_{03}$ : Performance of CRM components (CRMCP) does not influence CRM index (CRMI).

$\mathrm{H}_{4}$ : Aggregate perceived automated service quality ( $\left.\sum \mathrm{PASQ}\right)$ is influenced by CRM index (CRMI). 
$\mathrm{H}_{04}$ : Aggregate perceived automated service quality ( $\sum \mathrm{PASQ}$ ) is uninfluenced by CRM index (CRMI).

$\mathrm{H}_{5}$ : Customer satisfaction (CS) is influenced by CRM index (CRMI).

$\mathrm{H}_{05}$ : Customer satisfaction (CS) is uninfluenced by CRM index (CRMI).

$\mathrm{H}_{6}$ : Behavioural intentions are affected by CRM index (CRMI).

$\mathrm{H}_{06}$ : Behavioural intentions remain unaffected by CRM index (CRMI).

\section{Methodology}

The objectives of this study were to investigate the impact of automated service delivery channels (perceived automated service quality) on behavioural intentions (BI) of customers, to suggest a model to fit the relationship using SEM approach and to identify the nature of relationship between the variables using Causal Loop Diagramming (CLD). The study was conducted in two phases. To carry out this study, State Bank of India (SBI), the largest nationalized public sector bank in India was selected primarily because of its intensive branch network (availability of services), its upgradation to digitized platform towards service delivery and its adoption of CRM philosophy.

A structured questionnaire was developed to obtain the primary data. The questionnaire had four sections. Section-I asked questions about customers' perception of automated service quality, sectionII dealt with placing questions with regard to behavioural intentions of the customers, section-III targeted customer response in context with CRM components and their performance and section-IV attempted to collect the demographic profile of the customers. E-SERVQUAL scale developed by Zeithaml, Parasuraman and Malhotra (2005) was used to generate response about customers' perception of automated service quality across both the core and recovery dimensions. To obtain response with regard to behavioural intentions of customers as an output to customer satisfaction, the Behavioural Intention Battery (BIB) developed by Zeithaml et al (1996) was used. The respondents were asked to rate the statements related to automated banking service channels over a 7 point Likert scale (Alkibisi and Lind, 2011).

The study was carried out in two phases. Phase-I involved a pilot study to refine the test instrument with rectification of question ambiguity, refinement of research protocol and confirmation of scale reliability was given special emphasis (Teijlingen and Hundley, 2001). 20 respondents representing bank customers, bank employees and academic were included to conduct the pilot study. FGI was administered. Cronbach's $\alpha$ coefficient $(>0.7)$ established scale reliability (Nunnally and Bernstein, 1994). The second phase of the study was conducted by using a structured questionnaire which was distributed amongst 2000 SBI bank-customers at Asansol, Durgapur, Bolpur and Santiniketan, West Bengal, randomly selected with every $5^{\text {th }}$ customer leaving the bank premise was selected as sample. 'Usage-of-automated-banking-service' was used as critical-fit criteria while selecting samples. A total number of 1560 usable responses were generated with a response rate of $78.00 \%$. Exploratory factor analysis (EFA) was employed using principal axis factoring procedure with orthogonal rotation through VARIMAX process with an objective to understand the factor loadings/cross loadings across components. Cronbach's $\alpha$ was obtained to test the reliability of the data, Kaiser-Meyer-Olkin (KMO) was done for sample adequacy and Barlett's sphericity test was conducted. Structural equation modeling approach using Lisrel 8.80 was used to test the research model.

\section{Data analysis and interpretation}

The demographic data obtained were tabulated in Table-2: 
Table 2

Demographic data of the respondents

\begin{tabular}{|c|c|c|c|c|c|c|c|}
\hline $\begin{array}{l}\text { Demographic } \\
\text { Variables }\end{array}$ & Factors & Frequency & $\%$ & $\begin{array}{l}\text { Demographic } \\
\text { Variables }\end{array}$ & Factors & Frequency & $\%$ \\
\hline \multirow{2}{*}{ Gender } & Male & 1098 & $70.38 \%$ & \multirow{7}{*}{ Occupation } & Service [govt./prv] & 897 & $57.50 \%$ \\
\hline & Female & 462 & $29.62 \%$ & & Self employed & 376 & $24.10 \%$ \\
\hline \multirow{5}{*}{ Age } & $\leq 21$ years & 48 & $3.07 \%$ & & Professionals & 109 & $6.98 \%$ \\
\hline & $22-32$ years & 446 & $28.58 \%$ & & Student & 48 & $3.07 \%$ \\
\hline & $33-43$ years & 629 & $40.32 \%$ & & Housewives & 77 & $4.93 \%$ \\
\hline & $44-54$ years & 296 & $18.97 \%$ & & \multirow[t]{2}{*}{ Others [retd., VRS etc] } & \multirow[t]{2}{*}{53} & \multirow[t]{2}{*}{$3.42 \%$} \\
\hline & $\geq 55$ years & 141 & $9.06 \%$ & & & & \\
\hline \multirow{4}{*}{ Income } & $\leq$ Rs. 14999.00 & 129 & $8.26 \%$ & \multirow{4}{*}{$\begin{array}{l}\text { Educational } \\
\text { qualification }\end{array}$} & High school & 7 & $0.45 \%$ \\
\hline & Rs. 15000 -Rs. 24999.00 & 821 & $52.62 \%$ & & Graduate & 1119 & $71.73 \%$ \\
\hline & Rs. 25000 -Rs. 44999.00 & 427 & $27.37 \%$ & & Postgraduate & 397 & $25.44 \%$ \\
\hline & $\geq$ Rs. 45000.00 & 183 & $11.75 \%$ & & $\begin{array}{l}\text { Doctorate \& others } \\
\text { (CA, fellow etc) }\end{array}$ & 37 & $2.38 \%$ \\
\hline
\end{tabular}

Table 3

Rotated component matrix and Reliability statistics

\begin{tabular}{|c|c|c|c|c|c|c|c|}
\hline \multirow{2}{*}{ Var. } & \multirow{2}{*}{ Variable statement } & \multicolumn{5}{|c|}{ Factors } & \multirow[b]{2}{*}{ F6 } \\
\hline & & F1 & F2 & F3 & F4 & F5 & \\
\hline V1 & SBI's websites makes it easy to search what is required & .879 & & & & & \\
\hline V2 & Navigation is smooth in the SBI's websites & .802 & & & & & \\
\hline V3 & Page download is fast & .868 & & & & & \\
\hline V4 & Transaction takes place in real-time and does not freeze before completion & .791 & & & & & \\
\hline V5 & Information are well displayed in Banks' websites & .841 & & & & & \\
\hline V6 & SBI's web-services are simple to use & .821 & & & & & \\
\hline V7 & SBI's websites are always available for transaction & & 0.793 & & & & \\
\hline V8 & SBI's websites launch and run right away & & 0.809 & & & & \\
\hline V9 & SBI's website does not crash & & 0.821 & & & & \\
\hline V10 & Pages in SBI's websites do not freeze while transaction is on & & 0.798 & & & & \\
\hline V11 & SBI's website deliver services when promised & & & 0.809 & & & \\
\hline V12 & SBI's websites promptly delivers services & & & 0.837 & & & \\
\hline V13 & SBI's websites are truthful about their offerings & & & 0.799 & & & \\
\hline V14 & SBI website's make accurate promises about transactions & & & 0.824 & & & \\
\hline V15 & SBI's provides financial security and confidentiality & & & & .902 & & \\
\hline V16 & Web-interface is secured with virtual keyboard set-up for logging in & & & & .876 & & \\
\hline V17 & $\begin{array}{l}\text { SBI's websites can be trusted against misuse of information of transaction } \\
\text { details }\end{array}$ & & & & .891 & & \\
\hline V18 & $\begin{array}{l}\text { SBI's websites can be trusted against mishandling of personal information } \\
\text { stored }\end{array}$ & & & & .899 & & \\
\hline V19 & SBI's websites provide convenient options for cancelling transactions & & & & & .818 & \\
\hline V20 & SBI's websites deals well with cancelation of transactions & & & & & .821 & \\
\hline $\mathrm{V} 21$ & SBI's websites guide me in case of transactions not being processed & & & & & .791 & \\
\hline $\mathrm{V} 22$ & SBI's web-service takes care of problems promptly & & & & & .801 & \\
\hline V23 & $\begin{array}{l}\text { SBI's web-service has customer representative who shows willingness to } \\
\text { support/help }\end{array}$ & & & & & & .811 \\
\hline V24 & $\begin{array}{l}\text { SBI's websites provide a valid telephone number to contact the bank when } \\
\text { required }\end{array}$ & & & & & & .721 \\
\hline V25 & $\begin{array}{l}\text { SBI's website offers the facility to speak live to an authorized ervice if there } \\
\text { is a problem }\end{array}$ & & & & & & .781 \\
\hline \multicolumn{2}{|r|}{ Cronbach's $\alpha$} & 0.95 & 0.903 & 0.921 & 0.929 & 0.943 & 0.926 \\
\hline \multicolumn{2}{|c|}{ KMO measure for sampling adequacy } & \multicolumn{6}{|c|}{0.891} \\
\hline \multicolumn{2}{|c|}{ Initial eigen values } & 5.17 & 4.502 & 3.332 & 3.001 & 2.321 & 2.002 \\
\hline \multicolumn{2}{|c|}{$\%$ of variance } & 19.8 & 13.891 & 10.029 & 9.881 & 8.021 & 7.703 \\
\hline \multicolumn{2}{|c|}{ Cumulative \% } & 19.8 & 33.773 & 43.802 & 53.683 & 61.704 & 69.407 \\
\hline
\end{tabular}

Table 3 represents the rotated component matrix following the exploratory factor analysis. The Cronbach's $\alpha$ value for all the measures (except three items of core E-SQUAL namely 'the site enables me to get on to it quickly', 'the site makes items available for delivery within a suitable time frame, 'it has in-stock the items the company claims to have' and for the five items of recovery ESQUAL namely 'the site compensates me for problems it creates', 'it compensates me when what I 
ordered does not arrive on time', 'it picks up items I want to return from my home or business', 'the site offers a meaningful guarantee' and 'it offers the ability to speak to alive person if there is a problem') exceeded the minimum standard of .7 (Nunnally \& Bernstein, 1994) suggesting and confirming about the reliability of the measures. The items which were loaded with a lesser value to .7 were subsequently deleted.

The 33 variables (including both core and recovery items of E-SERVQUAL) were reduced to 25 variables. Variables having factor loading scores of $<0.7$ were discarded. The variables were grouped into six dimensions according to the factor loading scores and were nomenclated as in Table- 4 .

Table 4

Dimensions

\begin{tabular}{ccc}
\hline Variables & Dimension & Items \\
\hline V1-V6 & Efficiency & \\
V7-V10 & Web-System & Core items \\
V11-V14 & Commitment & \\
V15-V18 & Security & \multirow{2}{*}{ Recovery items } \\
\hline V19-V22 & Responsiveness & Contact \\
\hline
\end{tabular}

To test hypothesis 1 , the customer satisfaction score was obtained for an individual by calculating the mean of response over the items (4) namely 'satisfaction with respect to SBI's website design', 'satisfaction with regard to ease of navigation', 'satisfaction with regard to ease of use' and 'satisfaction with regard to privacy and accuracy of transaction'. The degree of satisfaction was generated over a 7 point Likert scale. Correlation (Table-5) results exhibited a strong and positive relationship between perceived automated service quality (PASQ) and customer satisfaction (CS): $\mathrm{r}=.494 * *, \mathrm{p}<.001$.

\section{Table 5}

Bivariate correlation between perceived automated service quality (PASQ) and customer satisfaction (CS)

\begin{tabular}{cccc}
\hline & & CS & PASQ \\
\hline CS & Pearson Correlation & 1.000 & $.494^{* *}$ \\
& Sig. (2-tailed) & & .000 \\
& $\mathrm{~N}$ & 1560.000 & 1560 \\
\hline PASQ & Pearson Correlation & $.494^{* *}$ & 1.000 \\
& Sig. (2-tailed) & .000 & 1560.000 \\
\hline
\end{tabular}

** Correlation significant at 0.01 level (2-tailed)

To assess the strength of associationship between the variables and to understand the predictive capability of the independent variable (PASQ) to predict the dependent variable (CS), simple regression analysis was used. The results of the regression analysis have been presented in Table- 6 . The model summary revealed that the $\mathrm{R}^{2}$ and adjusted $\mathrm{R}^{2}$ values are .155 and .153 respectively which indicate that perceived automated service quality measures $15.50 \%$ of the variation in customer satisfaction (dependent variable).

Table 6

Regression results

\begin{tabular}{ccccccc}
\hline \multicolumn{2}{c}{ Model summary } & \multicolumn{2}{c}{ ANOVA } & \multicolumn{3}{c}{ Regression coefficients } \\
\hline $\mathrm{R}^{2}$ & Adjusted $\mathrm{R}^{2}$ & $\mathrm{f}$ & $\mathrm{Sig}$. & $\beta$ & $\mathrm{t}$ & Sig. \\
.155 & .153 & 103.031 & .000 & .516 & 10.158 & .000 \\
\hline
\end{tabular}

a. Dependent variable: Customer satisfaction (CS)

b. Predictor: Perceived automated service quality (PASQ) 
The results of ANOVA established that the variation showed by the service quality was significant at $1 \%$ level $(\mathrm{f}=103.031, \mathrm{p}<.001)$. The standardised regression coefficient results confirmed that the predictive capacity of perceived automated service quality (PASQ) to predict the degree of customer satisfaction has statistical significance and is positively correlated $(\beta=.516, \mathrm{t}=10.158, \mathrm{p}<.001)$. Hypothesis-1 has been accepted. The Behavioural Intention Battery (Zeithaml et al, 1996) was used to obtain the behavioural intention scores of the respondents across five dimensions (13 items) of the same namely loyalty, will-to-pay-more, internal response (positive behavioural intention indicators) and propensity-to-switch and external response (negative behavioural intention indicators). Correlation matrix (Table 7) revealed that customer satisfaction (CS) exhibited a strong and positive relationship with loyalty $\left(\mathrm{r}=.491^{* *}, \mathrm{p}<.001\right)$, will-to-pay-more $\left(\mathrm{r}=.321^{* *}, \mathrm{p}<.001\right)$ and internal response $\left(\mathrm{r}=.354^{* *}, \mathrm{p}<.001\right)$ while $\mathrm{CS}$ revealed a negative relationship with propensity-to-switch $(\mathrm{r}=$ $\left..108^{*}, \mathrm{p}<.005\right)$ and external response $\left(\mathrm{r}=-.238^{* *}, \mathrm{p}<.001\right)$ indicating that satisfied customers with regard to their bank $(\mathrm{SBI})$ tend to exhibit positive behavioural intentions.

Table 7

Correlation matrix between behavioural intention (BI) dimensions and customer satisfaction (CS)

\begin{tabular}{|c|c|c|c|c|c|c|c|}
\hline & & $\mathrm{CS}$ & Loyalty & Will2pay & Propensity2s & Externalres & Internalrespo \\
\hline \multirow{3}{*}{ CS } & Pearson Correlation & 1.000 & $.491^{* *}$ & $.321^{* *}$ & $-.108^{*}$ & $-.238^{* *}$ & $.354^{* *}$ \\
\hline & Sig. (2-tailed) & & .000 & .000 & .003 & .000 & .000 \\
\hline & $\mathrm{N}$ & 1560 & 1560 & 1560 & 1560 & 1560 & 1560 \\
\hline \multirow{3}{*}{ Loyalty } & Pearson Correlation & $.491^{* *}$ & 1.000 & -.045 & .079 & .020 & $.744^{* *}$ \\
\hline & Sig. (2-tailed) & .000 & & .304 & .069 & .653 & .000 \\
\hline & $\mathrm{N}$ & 1560 & 1560 & 1560 & 1560 & 1560 & 1560 \\
\hline \multirow{3}{*}{ Will2paymore } & Pearson Correlation & $.321^{* *}$ & -.045 & 1.000 & $-.111^{*}$ & .062 & .010 \\
\hline & Sig. (2-tailed) & .000 & .304 & & .011 & .158 & .812 \\
\hline & $\mathrm{N}$ & 1560 & 1560 & 1560 & 1560 & 1560 & 1560 \\
\hline \multirow{3}{*}{ Propensity2switch } & Pearson Correlation & $-.108^{*}$ & .079 & $-.111^{*}$ & 1.000 & $-.105^{*}$ & $.109^{*}$ \\
\hline & Sig. (2-tailed) & .003 & .069 & .011 & & .016 & .012 \\
\hline & $\mathrm{N}$ & 1560 & 1560 & 1560 & 1560 & 1560 & 1560 \\
\hline \multirow{3}{*}{ Externalresponse } & Pearson Correlation & $-.238^{* *}$ & .020 & .062 & $-.105^{*}$ & 1.000 & .057 \\
\hline & Sig. (2-tailed) & .000 & .653 & .158 & .016 & & .188 \\
\hline & $\mathrm{N}$ & 1560 & 1560 & 1560 & 1560 & 1560 & 1560 \\
\hline \multirow{3}{*}{ Internalresponse } & Pearson Correlation & $.354^{* *}$ & $.744^{* *}$ & .010 & $.109^{*}$ & .057 & 1.000 \\
\hline & Sig. (2-tailed) & .000 & .000 & .812 & .012 & .188 & \\
\hline & $\mathrm{N}$ & 1560 & 1560 & 1560 & 1560 & 1560 & 1560 \\
\hline
\end{tabular}

**Correlation is significant at 0.01 level (2-tailed), *Correlation is significant at 0.05 level (2-tailed)

Table 8

CRM components

\begin{tabular}{|c|c|c|}
\hline Component & Dimensions & Variables \\
\hline \multirow{5}{*}{ People } & \multirow{3}{*}{ Empathy } & 1. Individual attention to customers \\
\hline & & 2. Understands specific need of customers \\
\hline & & 3. Employees have customers' best interest at heart \\
\hline & \multirow{2}{*}{ Responsiveness } & 4. Employees instill confidence in customers \\
\hline & & 5. Employees deal with public situations carefully \\
\hline \multirow{7}{*}{ Process } & \multirow{2}{*}{ Single Window (SWO) Service } & 6. Ease of in-premise transaction \\
\hline & & 7. Assorted service range \\
\hline & \multirow{3}{*}{ Know Your Customer (KYC) policy } & 8. Comprehensive information about customer \\
\hline & & 9. Better segmentation of customers \\
\hline & & 10. Better understanding of customers' specific need \\
\hline & \multirow{2}{*}{ Multi-Channel Integration (MCI) } & 11. Seamless and disintermediated delivery process \\
\hline & & 12. Access to multiple channels for transaction \\
\hline \multirow{5}{*}{ Technology } & Unified integrator & 13. Core Banking platform (CBS) \\
\hline & Mobility enhancement & 14. Mobile computing/Mobile commerce \\
\hline & Information Communication Technology (ICT) & 15. Internet \\
\hline & Automated ancillary process & 16. Automated Vending Machines (in-premise) \\
\hline & Security & 17. Digital vigilance system (in-premise) \\
\hline
\end{tabular}


The Pearson 'r' correlation coefficient suggested that satisfied customers of State Bank of India are likely to remain associate with the bank in future, on the basis of significant correlationship with 'loyalty' and 'willing to pay more' dimensions of BIB. Further to this the respondents demonstrated confidence in the bankers (internal response) when faced with a problem. Hypothesis-2 was accepted. CRM requires the proper integration of its components namely people, process and technology to ensure a successful adoption and link-up with the business process. These are the three key areas that touch the customer. The response of performance of CRM components were taken on these three touch-points, the CRM-components: People, Process \& Technology, their dimensions and their corresponding variables (Table 8). A 7 point Likert scale was used to obtain the response from the respondents about the performance of the three CRM components.

Factor analysis validated the measures used for Customer Relationship Management Index (CRMI) namely its three components people, process and technology. Exploratory factor analysis was deployed using orthogonal rotation. The reliability index was obtained as $>0.70$. The convergent validity was found to be $>0.60$ for all the items. Factor loading $<.500$ were discarded. Table- 9 displayed the results of factor analysis

\section{Table 9}

Factor structure of variables $(\mathrm{N}=712)$

\begin{tabular}{|c|c|c|c|c|c|}
\hline Factor & $\begin{array}{c}\text { Eigenval } \\
\text { ues }\end{array}$ & $\begin{array}{c}\text { Cronbach's } \\
\alpha\end{array}$ & Items & $\begin{array}{c}\text { Factor } \\
\text { loadings }\end{array}$ & $\begin{array}{c}\text { Convergent } \\
\text { validity }\end{array}$ \\
\hline People & 4.09 & 0.91 & $\begin{array}{l}\text { 1. Individual attention to customers } \\
\text { 2. Understands specific needs of customers } \\
\text { 3. Employees have customers' best interest at heart } \\
\text { 4. Employees instill confidence in customers } \\
\text { 5. Employees deal with public situation carefully }\end{array}$ & $\begin{array}{l}0.811 \\
0.802 \\
0.807 \\
0.786 \\
0.723\end{array}$ & $\begin{array}{l}0.862 \\
0.823 \\
0.816 \\
0.791 \\
0.732\end{array}$ \\
\hline Process & 4.21 & 0.89 & $\begin{array}{l}\text { 6. Ease of in-premise transactions } \\
\text { 7. Assorted service range } \\
\text { 8. Comprehensive information about customers } \\
\text { 9. Better segmentation of customers } \\
\text { 10. Better understanding of customers' demand } \\
\text { 11. Seamless delivery process } \\
\text { 12. More than one channel to enter into transaction }\end{array}$ & $\begin{array}{l}0.818 \\
0.809 \\
0.789 \\
0.865 \\
0.843 \\
0.761 \\
0.707\end{array}$ & $\begin{array}{l}0.823 \\
0.811 \\
0.797 \\
0.875 \\
0.857 \\
0.772 \\
0.714\end{array}$ \\
\hline Technology & 4.55 & 0.94 & $\begin{array}{l}\text { 13. CBS efficiency } \\
\text { 14. Mobile-technology/mobile commerce applications } \\
\text { 15. Internet enabled banking efficiency } \\
\text { 16. Auto-vending machine (in-premise) facility available } \\
\text { 17. Digital surveillance (in-premise) facility available }\end{array}$ & $\begin{array}{l}0.879 \\
0.851 \\
0.836 \\
0.818 \\
0.841\end{array}$ & $\begin{array}{l}0.891 \\
0.872 \\
0.844 \\
0.829 \\
0.855\end{array}$ \\
\hline
\end{tabular}

Table-10 and Table-11 displayed the relative weight of eigenvalue (RWE) and average factor value (AFV) respectively, which were considered for calculating the CRMI.

Table 10

Relative weight of eigenvalue (RWE)

\begin{tabular}{lcc}
\hline Factor & Eigenvalue & RWE \\
\hline People & 4.09 & 0.31 \\
\hline Process & 4.21 & 0.32 \\
\hline Technology & 4.55 & 0.37 \\
\hline Total & 12.85 & 1.00 \\
\hline
\end{tabular}

Table 11

Average factor value (AVF)

\begin{tabular}{cccc}
\hline Organization & People (CRMCP1) & Process (CRMCP2) & Technology (CRMCP3) \\
\hline SBI & 0.49 & 0.57 & 0.75 \\
\hline
\end{tabular}


Calculating for Customer Relationship Management Components' performance (CRMCP) as per the following equation, we get

$$
\begin{aligned}
C R M C P=R W E_{C R M C P 1} A V F_{C R M C P 1}+ & R W E_{C R M C P 2} A V F_{C R M C P 2}+R W E_{C R M C P} A V F_{C R M C P 3} \\
C R M C P & =(0.31 * 0.49)+(0.32 * 0.57)+(0.37 * 0.75) \\
& =0.1911+0.1824+0.2775 \\
& =0.6510
\end{aligned}
$$

Therefore, calculating for CRMI as per Eq. (3),

$$
C R M I=\frac{1}{1+e^{0.6510}}
$$

$\mathrm{CRMI}=0.34$

The CRM component performance was obtained for each component by calculating the mean value of response for each individual and an aggregate value was calculated taking all the three components taken together. Bivariate correlation was applied to understand the relationship between the CRM component performance (CRMCP) and the CRM index (CRMI). The results were displayed in Table12. The correlation was found to be significant $(r=.267 * *, p<.001)$

Table 12

Bivariate correlation between CRM component performance (CRMCP) and CRM index (CRMI)

\begin{tabular}{cccc}
\hline & & CRMI & CRMCP \\
\hline CRMI & Pearson Correlation & 1.000 & $.267^{* *}$ \\
& Sig. (2-tailed) & & .000 \\
& $\mathrm{~N}$ & 1560.000 & 1560 \\
\hline CRMCP & Pearson Correlation & $.267^{* *}$ & 1.000 \\
& Sig. (2-tailed) & .000 & 1560 \\
\hline ** Correlation significant at 0.01 level (2-tailed) & $\mathrm{N}$ & 1560.000 &
\end{tabular}

Simple regression analysis was performed to understand the predictive capacity of CRM component performance (CRMCP) towards predicting CRM index (CRMI). The results of regression analysis were displayed in Table-13. The $\mathrm{R}^{2}$ and adjusted $\mathrm{R}^{2}$ were found to be .484 and .483 respectively confirming that CRM component performance (CRMCP) measures $48.40 \%$ of the variation in CRM index (dependent variable). ANOVA established that the variation showed by the CRMCP was significant at $1 \%$ level $(\mathrm{f}=17.634, \mathrm{p}<.001)$. The standardised regression coefficient results confirmed that the predictive capacity of CRM component performance (CRMCP) to predict the enhancement of CRM index (CRMI) has statistical significance and is positively correlated $(\beta=.513, \mathrm{t}=6.763, \mathrm{p}<.001)$. The regression equation can be formed as:

$Y=a x+b$, where $Y$ stands for the dependent variable (CRMI), 'a' stands for the slope, ' $\mathrm{x}$ ' stands for the predictor (CRMCP) and ' $b$ ', the constant. Replacing ' $a$ ' for slope value (.139) and ' $b$ ' for constant value (2.566) from the regression results, the predictive equation takes the following shape:

$\mathrm{Y}(\mathrm{CRMI})=.139 * \mathrm{x}(\mathrm{CRMCP})+\mathrm{b}(2.566)$. Hypothesis-3 has been accepted. To explore the possible linkage between performance of CRM components and aggregate perceived automated service quality ( $\sum$ PASQ) correlation analysis was performed between CRM -index (CRMI) and ( $\sum$ PASQ) $\left(\mathrm{r}=.559^{* *}, \mathrm{p}<.001\right)$. Table 14 revealed that aggregate perceived automated service quality is significantly and positively correlated with CRM-index suggesting that an improvement in CRM- 
components' efficiency performance will enhance the perceived automated service quality of customers.

\section{Table 13}

Regression results

\begin{tabular}{rcccccccc}
\hline \multicolumn{2}{c}{ Model summary } & \multicolumn{2}{c}{ ANOVA } & \multicolumn{2}{c}{ Unstandardized regression coeff. } & \multicolumn{3}{c}{ Standardised regression coeff. } \\
\hline $\mathrm{R}^{2}$ & Adj. $\mathrm{R}^{2}$ & $\mathrm{f}$ & Sig. & $\mathrm{B}$ & Std. error & $\beta$ & $\mathrm{t}$ & Sig. \\
.484 & .483 & 17.634 & .000 & 2.566 & .176 & .513 & 6.763 & .000 \\
\hline $\begin{array}{l}\text { a. Dependent variable: CRM index (CRMI) } \\
\text { b. Predictor: CRM component performance (CRMCP) }\end{array}$
\end{tabular}

Table 14

Correlation between $\sum$ PASQ and CRMI

\begin{tabular}{cccc}
\hline & & 2PASQ & CRMI \\
\hline \multirow{2}{*}{ ¿PASQ } & Pearson Correlation & 1.000 & $.559^{* *}$ \\
& Sig. (2-tailed) & 1560 & .000 \\
\hline \multirow{2}{*}{ CRMI } & $\mathrm{N}$ & $.559^{* *}$ & 1560 \\
& Pearson Correlation & .000 & 1.000 \\
& Sig. (2-tailed) & 1560 & 1560 \\
\hline
\end{tabular}

** Correlation is significant at 0.01 level (2-tailed)

Regression analysis (Table-15) was performed to examine the predictability and strength of associationship between CRMI (independent variable) and $\sum$ PASQ (dependent variable). The model summary showed $\mathrm{R}^{2}$ and adjusted $\mathrm{R}^{2}$ to be as .580 and .578 indicating that CRM index (CRMI) measures $58.00 \%$ of the variation in aggregate perceived automated service quality ( $\sum$ PASQdependent variable) which is considered to be significant enough for predictability of the model. ANOVA established that the variation showed by the perceived automated service quality was significant at $1 \%$ level $(\mathrm{f}=467.389, \mathrm{p}<.001)$. Regression coefficients confirmed a strong associationship between CRMI and $\sum$ PASQ $(\beta=.549, \mathrm{t}=29.541, \mathrm{p}<.001)$ and that CRMI could be an effective predictor to $\sum$ PASQ thereby suggesting dependency of $\sum$ PASQ on CRMI. Hypothesis-4 was accepted.

\section{Table 15}

Summary of regression results

\begin{tabular}{cccccccc}
\hline & Model Summary & \multicolumn{2}{c}{ ANOVA } & \multicolumn{3}{c}{ Regression coefficients } \\
\hline $\mathrm{R}$ & $\mathrm{R}^{2}$ & adjusted $\mathrm{R}^{2}$ & $\mathrm{~F}$ & $\mathrm{sig}$ & $\beta$ & $\mathrm{t}$ & sig. \\
\hline .762 & .580 & .578 & 467.389 & .000 & .549 & 29.541 & .000 \\
\hline
\end{tabular}

a. Dependent variable: Aggregate perceived service quality ( $\sum$ PASQ)

b. Predictor: CRM index (CRMI)

To test Hypothesis-5, bivariate correlation was deployed to assess the relationship between customer satisfaction (CS-dependent variable) and CRM index (CRMI-independent variable). The Pearson coefficient $(\mathrm{r})$ was obtained and displayed in Table-16. The result $\left(\mathrm{r}=.421^{* *}, \mathrm{p}<.001\right)$ revealed a strong and positive correlation between customer satisfaction (CS) and CRM-index (CRMI) suggesting that higher the CRMI, higher will be the customer satisfaction. Hypothesis-5 was accepted.

To test Hypothesis-6, multiple correlation was used to understand the correlationship between CRM index (CRMI) and the dimensions of behavioural intentions. The results were displayed in Table-17. It was revealed that CRMI shared a strong and positive correlation with loyalty $\left(\mathrm{r}=.683^{* *}, \mathrm{p}<.001\right)$, 
will-to-pay-more $\left(\mathrm{r}=.274^{* *}, \mathrm{p}<.001\right)$ and moderately strong relationship with internal response $\left(\mathrm{r}=.095^{*}, \mathrm{p}<.005\right)$, while CRMI revealed a significant negative correlationship with propensity-toswitch $\left(\mathrm{r}=-.196^{* *}, \mathrm{p}<.001\right)$ suggesting an inverse relationship with the same.

Table 16

Correlation between Customer satisfaction (CS) and CRM index (CRMI)

\begin{tabular}{cccc}
\hline & & CS & CRMI \\
\hline \multirow{2}{*}{ CS } & Pearson Correlation & 1.000 & $.421^{* *}$ \\
& Sig. (2-tailed) & & .000 \\
& $\mathrm{~N}$ & 1560 & 1560 \\
\hline \multirow{2}{*}{ CRMI } & Pearson Correlation & $.421^{* *}$ & 1.000 \\
& Sig. (2-tailed) & .000 & \\
${ }^{* * *}$ Correlation is significant at 0.01 level (2-tailed) & $\mathrm{N}$ & 1560 & 1560 \\
\hline
\end{tabular}

Table 17

Multiple correlation between BIB dimensions and CRM index (CRMI)

\begin{tabular}{|c|c|c|c|c|c|c|c|}
\hline & & CRMI & Loyalty & $\begin{array}{c}\text { Propensity } \\
\text { to switch }\end{array}$ & $\begin{array}{l}\text { Will-to- } \\
\text { pay more }\end{array}$ & $\begin{array}{l}\text { External } \\
\text { response }\end{array}$ & $\begin{array}{l}\text { Internal } \\
\text { response }\end{array}$ \\
\hline \multirow{3}{*}{ CRMI } & Pearson Correlation & 1.000 & $.683^{* *}$ & $-.196^{* *}$ & $.274^{* *}$ & -.069 & $.095^{*}$ \\
\hline & Sig. (2-tailed) & & .000 & .000 & .000 & .065 & .011 \\
\hline & $\mathrm{N}$ & 1560.000 & 1560 & 1560 & 1560 & 1560 & 1560 \\
\hline \multirow{3}{*}{ Loyalty } & Pearson Correlation & $.683^{* *}$ & 1.000 & -.012 & $.256^{* *}$ & $-.127^{* *}$ & $.349^{* *}$ \\
\hline & Sig. (2-tailed) & .000 & & .743 & .000 & .001 & .000 \\
\hline & $\mathrm{N}$ & 1560 & 1560.000 & 1560 & 1560 & 1560 & 1560 \\
\hline \multirow{3}{*}{$\begin{array}{l}\text { Propensity to } \\
\text { switch }\end{array}$} & Pearson Correlation & $-.196^{* * *}$ & -.012 & 1.000 & -.010 & -.061 & $.178^{* *}$ \\
\hline & Sig. (2-tailed) & .000 & .743 & & .785 & .105 & .000 \\
\hline & $\mathrm{N}$ & 1560 & 1560 & 1560.000 & 1560 & 1560 & 1560 \\
\hline \multirow{3}{*}{$\begin{array}{l}\text { Will-to-pay } \\
\text { more }\end{array}$} & Pearson Correlation & $.274^{* *}$ & $.256^{* *}$ & -.010 & 1.000 & $-.248^{* *}$ & $.253^{* *}$ \\
\hline & Sig. (2-tailed) & .000 & .000 & .785 & & .000 & .000 \\
\hline & $\mathrm{N}$ & 1560 & 1560 & 1560 & 1560.000 & 1560 & 1560 \\
\hline \multirow{3}{*}{$\begin{array}{l}\text { External } \\
\text { response }\end{array}$} & Pearson Correlation & -.069 & $-.127^{* * *}$ & -.061 & $-.248^{* *}$ & 1.000 & $.125^{* *}$ \\
\hline & Sig. (2-tailed) & .065 & .001 & .105 & .000 & & .001 \\
\hline & $\mathrm{N}$ & 712 & 712 & 712 & 712 & 1560.000 & 712 \\
\hline \multirow{3}{*}{$\begin{array}{l}\text { Internal } \\
\text { response }\end{array}$} & Pearson Correlation & $.095^{*}$ & $.349^{* *}$ & $.178^{* *}$ & $.253^{* *}$ & $.125^{* *}$ & 1.000 \\
\hline & Sig. (2-tailed) & .011 & .000 & .000 & .000 & .001 & \\
\hline & $\mathrm{N}$ & 1560 & 1560 & 1560 & 1560 & 1560 & 1560.000 \\
\hline
\end{tabular}

Regression analysis was performed to assess the strength of associationship between behavioural intentions dimensions and CRM index and predictive capacity of CRM index to predict the behavioural consequences. A summated score for positive behavioural intention (variables: loyalty, will-to-pay-more and internal response) $(\mathrm{BI}+)$ and negative behavioural intention (variables: propensity-to-switch and external response) (BI-) was obtained for each individual by obtaining the mean of response against each corresponding variable. The results are displayed in Table-18

Table 18

Regression results

\begin{tabular}{rccccccccc}
\hline & \multicolumn{2}{c}{ Model } & \multicolumn{2}{c}{ ANOVA } & \multicolumn{2}{c}{ Unstandardized } & \multicolumn{2}{c}{ Standardised regression } \\
\cline { 2 - 10 } BI+ & $\mathrm{R}^{2}$ & Adj. $\mathrm{R}^{2}$ & $\mathrm{f}$ & Sig. & $\mathrm{B}$ & Std. error & $\beta$ & $\mathrm{t}$ & Sig. \\
& .366 & .365 & 304.052 & .000 & -.912 & .320 & .605 & 17.437 & .000 \\
\hline \multirow{2}{*}{$\mathrm{BI}-$} & $\mathrm{R}^{2}$ & Adj. $\mathrm{R}^{2}$ & $\mathrm{f}$ & Sig. & $\mathrm{B}$ & Std. error & $\beta$ & $\mathrm{t}$ & Sig. \\
& .153 & .151 & 105.766 & .000 & 2.929 & .217 & .391 & 10.284 & .000 \\
\hline
\end{tabular}

a. Dependent variable: $\mathrm{BI}(+), \mathrm{BI}(-)$

b. Predictor: CRM I(CRMI) 
Table 19

Summary representation of Confirmatory Factor Analysis (CFA)

\begin{tabular}{|c|c|c|c|c|c|c|c|c|c|c|}
\hline Factor indicators & $\chi^{2}$ & $\mathrm{df}$ & P-value & GFI & AGFI & CFI & NFI & RMSEA & Factor & $\alpha-$ \\
\hline Efficiency & 8.775 & 5 & 0.078 & 0.969 & 0.972 & 0.991 & 0.979 & 0.065 & & 0.981 \\
\hline EF1 & & & & & & & & & 0.837 & \\
\hline EF2 & & & & & & & & & 0.842 & \\
\hline EF3 & & & & & & & & & 0.804 & \\
\hline EF4 & & & & & & & & & 0.832 & \\
\hline EF5 & & & & & & & & & 0.799 & \\
\hline EF6 & & & & & & & & & 0.798 & \\
\hline EF7 & & & & & & & & & 0.887 & \\
\hline Web-System & 9.621 & 3 & 0.049 & 0.909 & 0.918 & 0.996 & 0.997 & 0.061 & & 0.979 \\
\hline WS1 & & & & & & & & & 0.898 & \\
\hline WS2 & & & & & & & & & 0.879 & \\
\hline WS3 & & & & & & & & & 0.845 & \\
\hline WS4 & & & & & & & & & 0.877 & \\
\hline Commitment & 10.001 & 4 & 0.287 & 0.972 & 0.969 & 0.974 & 0.991 & 0.087 & & 0.966 \\
\hline COM1 & & & & & & & & & 0.843 & \\
\hline COM2 & & & & & & & & & 0.826 & \\
\hline COM3 & & & & & & & & & 0.809 & \\
\hline COM4 & & & & & & & & & 0.856 & \\
\hline COM5 & & & & & & & & & 0.818 & \\
\hline Security & 4.712 & 2 & 0.061 & 0.944 & 0.932 & 0.949 & 0.966 & 0.059 & & 0.941 \\
\hline SEC1 & & & & & & & & & 0.828 & \\
\hline SEC2 & & & & & & & & & 0.764 & \\
\hline SEC3 & & & & & & & & & 0.801 & \\
\hline Responsiveness & 8.197 & 3 & 0.116 & 0.980 & 0.974 & 0.951 & 0.952 & 0.020 & & 0.891 \\
\hline RES1 & & & & & & & & & 0.861 & \\
\hline RES2 & & & & & & & & & 0.865 & \\
\hline RES3 & & & & & & & & & 0.708 & \\
\hline RES4 & & & & & & & & & 0.798 & \\
\hline Contact & 8.991 & 2 & 0.076 & 0.979 & 0.955 & 0.969 & 0.971 & 0.073 & & 0.942 \\
\hline CON1 & & & & & & & & & 0.872 & \\
\hline CON2 & & & & & & & & & 0.809 & \\
\hline BI+ & 9.219 & 4 & 0.031 & 0.919 & 0.917 & 0.921 & 0.923 & 0.073 & & 0.929 \\
\hline $\mathrm{BI}+1$ & & & & & & & & & 0.881 & \\
\hline $\mathrm{BI}+2$ & & & & & & & & & 0.781 & \\
\hline $\mathrm{BI}+3$ & & & & & & & & & 0.709 & \\
\hline BI- & 7.891 & 2 & 0.041 & 0.946 & 0.941 & 0.978 & 0.938 & 0.049 & & 0.911 \\
\hline BI-1 & & & & & & & & & 0.791 & \\
\hline BI-2 & & & & & & & & & 0.715 & \\
\hline $\mathrm{CS}$ & 9.693 & 4 & 0.091 & 0.967 & 0.981 & 0.991 & 0.987 & 0.051 & & 0.997 \\
\hline CS1 & & & & & & & & & 0.873 & \\
\hline $\mathrm{CS} 2$ & & & & & & & & & 0.859 & \\
\hline $\mathrm{CS} 3$ & & & & & & & & & 0.786 & \\
\hline CRMI & 8.165 & 2 & 0.087 & 0.912 & 0.919 & 0.941 & 0.933 & 0.032 & & 0.972 \\
\hline CRMI1 & & & & & & & & & 0.821 & \\
\hline CRMI2 & & & & & & & & & 0.816 & \\
\hline CRMCP & 10.321 & 2 & 0.0912 & 0.966 & 0.987 & 0.965 & 0.942 & 0.079 & & 0.992 \\
\hline CRMCP1 & & & & & & & & & 0.910 & \\
\hline CRMCP2 & & & & & & & & & 0.899 & \\
\hline
\end{tabular}

To construct the nomological network structural equation modeling (SEM) was used to test the nomological validity of the proposed model. E-SERVQUAL, behavioural intentions, customer satisfaction and CRM computation (CRMI and CRMCP) scores for the individual dimensions were done by summating the ratings on their individual scale items which were used as indicators of the latent E-SERVQUAL, behavioural intentions (BI+ and BI-) and CRM items (CRMI and CRMCP). Confirmatory factor analysis was used to understand the dimensionality, convergence and discriminant validity for each construct to determine whether all the 42 indicators (including E- 
SERVQUAL, BI+ \& BI-, CRMI and CRMCP) measure the construct adequately as they had been assigned for.

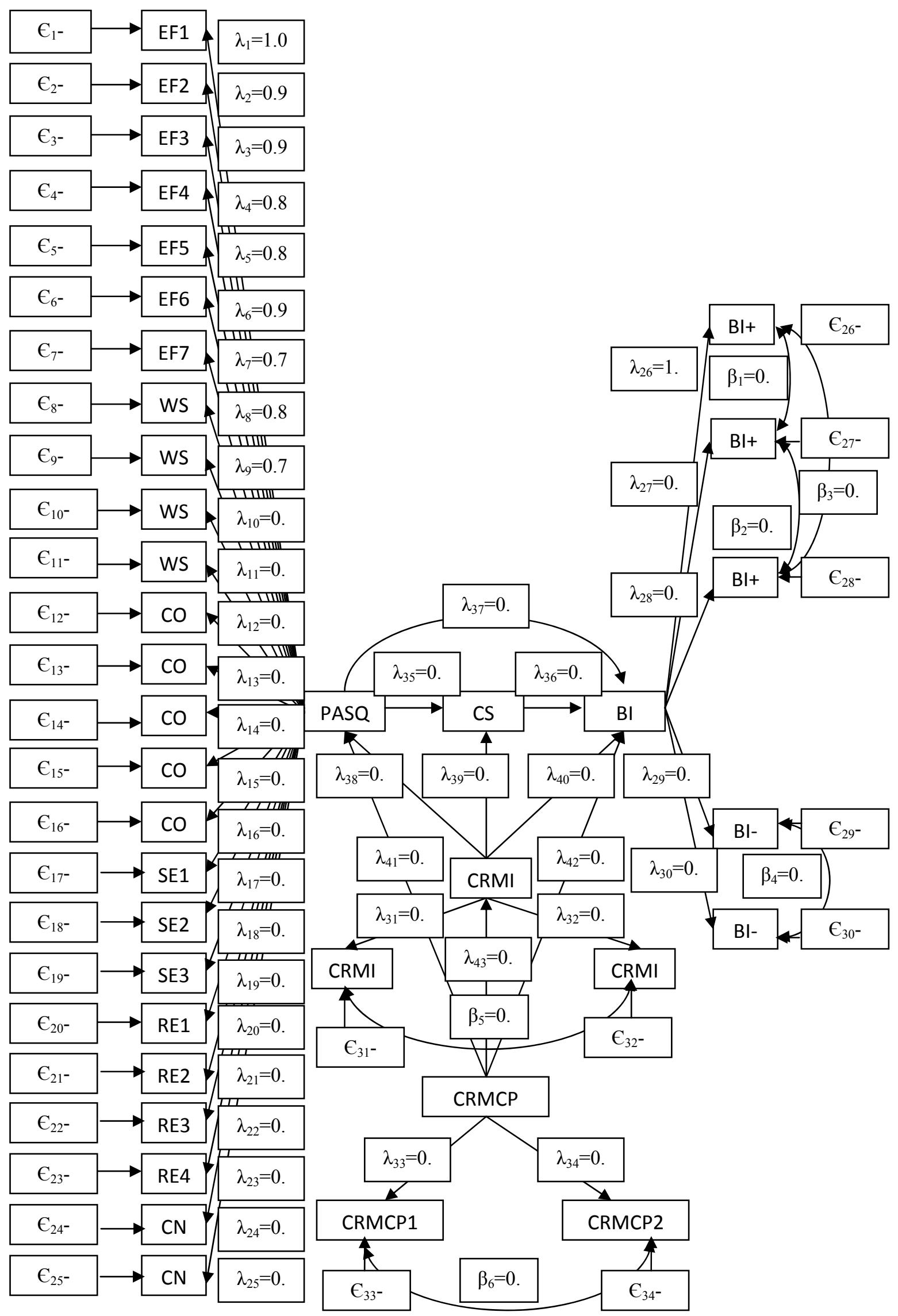

Fig. 2. Structural model showing the path analysis using SEM 
LISREL 8.80 programme was used to conduct the Structural Equation Modeling (SEM) and Maximum Likelihood Estimation (MLE) was applied to estimate the CFA models. A number of fitstatistics (Table-19) were obtained. The GFI, AGFI and NFI scores for all the constructs were found to be consistently $>.900$ indicating that a significant proportion of the variance in the sample variance-covariance matrix is accounted for by the model and a good fit has been achieved (Baumgartner and Homburg, 1996; Hair et al, 1998; Hulland, Chow and Lam, 1996; Kline, 1998; Holmes-Smith, 2002, Byrne, 2001). The CFI value for all the constructs were obtained as $>.900$ which indicated an acceptable fit to the data (Bentler, 1992). The RMSEA values obtained are $<0.08$ for an adequate model fit ( $\mathrm{Hu}$ and Bentler, 1999). The probability value of Chi-square is more than the conventional 0.05 level $(\mathrm{P}=0.20)$ indicating an absolute fit of the models to the data. The Cronbach's $\alpha$ values were consistently $>.7$ and hence the scale is reliable (Nunnally and Bernstein, 1994). The factor loadings for the items were also significant $(>.500)$.

Structural Equation Modeling (SEM) was used to test the relationship among the constructs. A number of fit-indices namely Chi-square $/ \mathrm{df}=561 / 79$, GFI $=0.991$, AGFI $=0.987$, CFI $=0.980$, $\mathrm{NFI}=0.977$, RMSEA $=0.043$, expected cross validation index $(\mathrm{ECVI})=0.921$ were found to be significant. All the 43 paths drawn were found to be significant at $p<0.05$. The research model holds well (Fig.2) as the fit-indices supported adequately the model fit to the data. The double-curved arrows indicate co-variability of the latent variables. The residual variables (error variances) are indicated by $\epsilon_{1}, \epsilon_{2}, \epsilon_{3}$, etc. The regression weights are represented by $\lambda$. The co-variances are represented by $\beta$. To provide the latent factors an interpretable scale; one factor loading is fixed to 1 (Hox \& Bechger). The SEM disclosed the following direct and indirect and total effects of the independent variables on dependent variables (Table 20).

\section{Table 20}

Direct, indirect and total effects of independent variables on dependent variables

\begin{tabular}{|c|c|c|c|}
\hline Relating variables & Direct effects & Indirect effects & Total effects \\
\hline $\mathrm{PASQ} \longrightarrow \mathrm{CS}$ & 0.91 & & 0.910 \\
\hline $\mathrm{PASQ} \longrightarrow \mathrm{CS} \longrightarrow \mathrm{BI}(+)$ & & $.762(.91 * .90 * 1.00 * .98 * .95)$ & 0.762 \\
\hline $\mathrm{PASQ} \longrightarrow \mathrm{CS} \longrightarrow \mathrm{BI}(-)$ & & $.685(.91 * .90 * .92 * .91)$ & 0.685 \\
\hline $\mathrm{PASQ} \longrightarrow \mathrm{CS} \longrightarrow \mathrm{BI}(+)$ & & $.586(.77 * .91 * .90 * 1.00 * .98 * .95)$ & 0.586 \\
\hline $\mathrm{CRMI} \longrightarrow \mathrm{PASQ} \longrightarrow \mathrm{CS} \longrightarrow \mathrm{BI}(-)$ & & $.527(.77 * .91 * .90 * .92 * .91)$ & 0.527 \\
\hline $\mathrm{CRMCP} \longrightarrow \mathrm{CRMI} \longrightarrow \mathrm{PASQ} \rightarrow \mathrm{CS} \rightarrow \mathrm{BI}(+)$ & & $.544(.93 * .77 * .91 * .90 * 1.00 * .98 * .95)$ & 0.544 \\
\hline $\mathrm{CRMCP} \longrightarrow \mathrm{CRMI} \longrightarrow \mathrm{PASQ} \longrightarrow \mathrm{CS} \longrightarrow \mathrm{BI}(-)$ & & $.490(.93 * .77 * .91 * .90 * .92 * .91)$ & 0.490 \\
\hline $\mathrm{CRMI} \longrightarrow$ PASQ & 0.77 & & 0.770 \\
\hline
\end{tabular}

\section{Conclusion}

The rapid penetration of technology in the service domain has changed the entire perception of service quality. Integration of technology to deliver better services has been ensured by almost every service sector including the banks. The modernization and automation of State Bank of India (SBI) had been a significant event in the banking industry in India as, being the largest nationalized public sector bank in India, SBI has become the face of Indian electronic banking. Due to the phenomenal reach and penetration of SBI it was a challenge for the technologists to ensure a 360 degree technotransformation of the same. The results ensured that the automated (electronic) banking services penetrated the rural geo-demographic domain of India. The core-bank-system of SBI has changed the perception of banking and vis-à-vis quality perception. The study revealed that the automated service quality dimensions which proved to be significant in perceiving quality are efficiency, web-system, commitment, security, responsiveness and contact. It was revealed that the automated service quality was instrumental in assuring customer satisfaction across a wide range of demographic cross factors. The study also confirmed that the customers of SBI had gradually become habituated with automated banking services and are satisfied with the same as it established a strong and positive behavioural intention depicting intentions for loyalty, willing to pay more for services and addressing problems to internal customers only. The Customer Relationship Management (CRM) practice initiated by SBI 
seemed to have properly integrated with their automated operational procedures as the CRM components were found to influence the perceived automated service quality of customers in a positive way. The proposed research model also holds good as the model constructs fit the data thereby establishing a cause and effect relationship between the variables. The study was indicative of the shift and subsequent adoption of automated banking services in a semi-urban/rural set up. The CRM index approach may be used by the bankers as it hinted to be an effective indicator of customer satisfaction.

The study had geographical limitations as it has been restricted to Durgapur, Asansol, Bolpur and Santiniketan in West Bengal, which in future, can be widened to obtain a more generalized conclusion. In future the comparative studies can be initiated by including variables namely service differentiation and customization, zone of tolerance etc.

\section{References}

Alkibsi, S., \& Lind, M. (2011). Customer perceptions of technology-based banking service quality provided by banks operating in Yemen, European, Mediterranean \& Middle Eastern Conference on Information Systems 2011 (EMCIS2011) May 30-31 2011, Athens, Greece

Allison, P. D. (1999). Event History Analysis Regression for Longitudinal Event Data , Newbury Park, CA Sage Publications. ( 9-42). [EHA]

Al-hawari, M., Hartley, N., \& Ward, T. (2005). Measuring Banks Automated Service Quality A Confirmatory Factor Analysis Approach, Marketing Bulletin, 16(1).

Al-Hawari, M. \& Ward, T. (2006). The effect of automated service quality on Australian banks financial performance and the mediating role of customer satisfaction. Marketing Intelligence \& Planning, 24( 2), 127-47.

Avkiran, N. K. (1994). Developing an Instrument to Measure Customer Service Quality in Branch Banking. International Journal of Bank Marketing, 12(6), 10-18.

Babakus, E. \& Boller, G.W. (1992). An empirical assessment of the SERVQUAL scale. Journal of Business Research, 24, 253-268

Baumgartner, H., Homburg, C. (1996). Applications of structural equation modeling in marketing and consumer research A review. International Journal of Research in Marketing, 13, 139-161.

Bentler, P.M. (1992). On the fit of models to covariances and methodology to the Bulletin. Psychological Bulletin, 112(3), 400-404.

Baksi, A.K., \& Parida, B.B. (2011). Service quality and switching behavior of customers. Management Science Letters, 1(4), 405-414.

Baksi, A.K. (2012). Automated service quality and its behavioural consequences in CRM Environment: A structural equation modeling and causal loop diagramming approach. Management Science Letters, 2(4), 1239-1258.

Bolton, R., \& Drew, J. (1991a). A Longitudinal Analysis of the Impacts of Service Changes on Customer Attitudes. Journal of Marketing, 55(1), 1-9.

Broderick, A.J \& S. Vachirapornpuk (2002). Service quality in Internet banking The importance of customer role. Marketing Intelligence \& Planning, 20(6), 327 - 335.

Buckley, J. (2003). E-service and the public sector. Managing Service Quality, 13(6), 453- 462.

Byrne, B. M. (2001). Structural Equation Modeling with AMOS - Basic Concepts, Applications, and Programming.LEA, ISBN 0-8058-4104-0

Carman, J. M. (1990). Consumers perceptions of service quality an assessment of the SERVQUAL dimensions, Journal of Retailing, 66(1). 33-55.

Cox, J., \& Dale, B.G. (2001). Service quality and e-commerce An exploratory analysis , Managing service quality, 11(2), 121-131.

Cronin, J., \& Taylor, S.A. (1992). Measuring service quality: A re-examination and extension. Journal of Marketing, 56, 55-67. 
Cronin, J., \& Taylor, S. A. (1994). SERVPERF versus SERVQUAL reconciling performance-based and perceptions-minus-expectations measurement of service quality. Journal of Marketing, 58, (January) 125-131.

Crosby, L. A., \& Stephens, N. (1987). Effects of relationship marketing on satisfaction, retention, and prices in the life insurance industry. Journal of Marketing Research, 14, 404-11.

Cristobal, E., Flavian, C., \& Guinaliu, M. (2007). Perceived e-service quality Measurement validity and effects on consumer satisfaction and website loyalty. Managing Service Quality, 17(3), 317340.

Dabholkar, P. (1996). Consumer evaluations of new technology-based self-service options An investigation of alternative modes of service quality. International Journal of Research in Marketing, 13, 1, 29-51.

Dabholkar P (1994). Technology based service delivery. Advances in Service Marketing and Management, 3(1), 241-271.

Dekimpe, M.G., Steenkamp, J.E.M., Mellens, M. \& Abeele, P.V. (1997). Decline and variability in brand loyalty. International Journal of Research in Marketing, 5(14), 405-420.

Eric, P. J., Tom A. B., \& Charles, E. M. (2006). Operational challenges in call center Industry; a case study and resource based framework. Managing Service Quality Journal, 477-500.

Evans, J. R., \& Laskin, R. L. (1994). The relationship marketing process A conceptualization and application. Industrial Marketing Management, 23(5), 439-452.

Fassnacht, M., \& Koese, I. (2006). Quality of electronic services Conceptualizing and testing a hierarchical model. Journal of Service Research, 9(1), 19-31.

Field, J.M., Heim, G.R., \& Sinha, K.K. (2004). Managing quality in the e-service system Development and application of a process model. Productions and Operations Management, 13(4), 291-306.

Gefen, D. (2002). Customer loyalty in e-commerce. Journal of the Association for Information Systems, 3, 27-51.

Gerrard, P., \&Cunningham, J.B. (2003). The Diffusion of Internet Banking among Singapore Consumers. International Journal of Bank Marketing, 21(1), 16-28.

Gounaris, S., Dimitriadis, S., \& Stathakopoulos, V. (2005). Antecedents of perceived quality in the context of Internet retail stores. Journal of Marketing Management, 21(7), 669-682.

Gray, P., \& Byun, J. (2001). Customer Relationship Management. Centre for Research on Information Technology and Organizations, University of California

Grönroos, C. (1982). Strategic Management and Marketing in the Services Sector. Marketing Science, Cambridge, MA.

Grönroos, C. (1983). Strategic Management and Marketing in the Service Sector. Marketing Science Institute, Boston, MA.

Grönroos, C. (1984). A service quality model and its marketing implications. European Journal of Marketing,18(4), 36-44.

Hair, J.F., Anderson, R.E., Tatham, R.L., \& Black, W.C. (1998). Multivariate data analysis, $5^{\text {th }}$ ed., Prentice Hall, Upper Saddle, New jersey.

Hanzaee, K.H., \& Sadeghi, T. (2010). Customer satisfaction (CSFs) with online banking services in an Islamic country I.R. Iran. Journal of Islamic Marketing, 1(3), 249-267.

Heide, J. B. (1994). Interorganizational governance in marketing channels. Journal of Marketing, 58(1). 71-85.

Henderson J, McGoldrick E \& McAdam R, (2003). A critical review of e-service in Northern Ireland Electricity. Managing Service Quality, 13(6), 463-470.

Hernandez, J.M.C., \& Mazzon, J.A. (2007). Adoption of Internet Banking Proposition and Implementation of an Integrated Methodology Approach, International Journal of Bank Management, 25(2), 72-88.

Holmes-Smith, P. (2002). Applied Structural Equation Modeling. Canberra.

Hu, L., \& Bentler, P.M. (1999). Cutoff criteria for fit indexes in covariance structure analysis 
conventional criteria versus new alternatives. Structural Equation Modeling, 6(1). 1-55.

Hulland, J., Chow, Y.H., Lam, S. (1996). Use of causal models in marketing research A review. International Journal of Research in Management, 13(2), 181-197

Hox, J. J., \& Bechger, T. M. (1998). An introduction to structural equation modeling. Family Science Review, 11, 354-373.

Jacoby, J., \& Kyner, D.B. (1973). Brand loyalty versus repeat purchase behavior. Journal of Marketing Research, 10(1). 1-9.

Joseph, M. \& Stone, G. (2003). An empirical evaluation of US bank customer perceptions of the impact of technology in service delivery in the banking sector. International Journal of Retail \& Distribution Management, 31(4), 190-202.

Julian, C. C., \& Ramaseshan, B. (1994). The role of customer-contact personnel in the marketing of a retail bank's services. International Journal of Retail \& Distribution Management, 5, 29-34.

Jun, M., \& Cai, S. (2001). The key determinants of internet banking service quality a content analysis. The International Journal of Bank Marketing, 19(7), 276-291.

Kearns, D., \& Nadler, D. (1992) Prophets in the Dark How Xerox Reinvented Itself and Beat Back Japanese. New York Harper Collins Publishers.

Keaveney, S. M. (1995). Customer switching behavior in service industries an exploratory study. Journal of Marketing, 59, 71-82.

Khan, M.S., \& Mahapatra, S.S. (2009). Service quality evaluation in internet banking an empirical study in India , International. Journal Indian Culture and Business Management, 2(1), 30-46

Kim, M., Kim, J-H, \& Lennon, S.J. (2006). Online service attributes available on apparel retail websites An e-squal approach. Managing Service Quality, 16(1), 51-77.

Kim, M., \& Stoel, L. (2004). Apparel retailers Web site quality dimensions and satisfaction. Journal of Retailing and Consumer Services, 11, 109-117.

Kline, R. B. (1998). Principles and practices of structural equation modeling. New York Guilford.

Laforet, S., \& Li, X. (2005). Consumers Attitude Towards Online and Mobile Banking in China. International Journal of Bank Management, 23(5), 362-380.

Lehtinen, J.R, \& Lehtinen, U. (1982). Service quality a study of quality dimensions. Unpublished working paper, Service Management Institute, Helsinki .

Lee, G.G., \& Lin, H.F. (2005). Customer perceptions of e-service quality in online shopping , International Journal of Retail and Distribution Management, 33(2), 161-176.

Li, H., Liu, Y., \& Suomi, R. (2009). Measurement of e-service quality An empirical study on online travel service, Conference Proceedings, 17th European Conference on Information Systems, Verona

Llosa, S., Chandon, J.L., \& Orsingher, C. (1998). An empirical study of SERVQUAL s dimensionality. The Service Industries Journal, 18(2). 16-44.

Loiacono, E.T., Watson, R.T., \& Hoodhue, D.L. (2002). WEBQUAL Measure of website quality. Marketing Educators Conference Marketing theory and applications, 13, 432-437.

Macintosh, G., \& Lockshin, L. S. (1997). Retail relationships and loyalty: A multi-level perspective. International Journal of Research in Marketing, 14(5), 487-497.

Madu, C.N., \& Madu, A.A. (2002). Dimensions of e-quality. International Journal of Quality \& Reliability Management, 19(3), 246-259.

Malhotra, P., \& Singh, B. (2007) Determinants of internet banking adoption by banks in India. Internet Research, 17(3), 323-339.

Meuter, M., Ostrom, A., Roundtree, R., \& Bitner, M. (2000). Self-service technology Understand customer satisfaction with technology-based service encounters. Journal of Marketing, 64(3), 5064.

Mukherjee, A., \& Nath, P. (2003). A model of trust in online relationship banking. International Journal of Bank Management, 21(1), 5-15.

Nguyen, T., Sherif, J., \& Newby, M. (2007). Strategies for successful CRM implementation. Information management and Computer security, 15(2), 76-95

Nunnally, J.C., \& Bernstein, H. (1994). Psychometric Theory. New York, McGraw-Hill 
Oliver, R. L. (1981). A cognitive model of the antecedents and consequences of satisfaction decisions. Journal of Marketing Research, 17, 460-469.

Parasuraman, A., Berry, L. L., \& Zeithaml, V. A. (1985). A conceptual model of service quality and its implications for future research. Journal of Marketing (pre-1986), 49, 41-50.

Parasuraman, A., Zeithaml, V. A., \& Berry, L. L. (1988). A multiple-item scale for measuring consumer perceptions of service quality. Journal of Retailing, 64, 12-37.

Parasuraman, A., Berry, L. L., \& Zeithaml, V. A. (1991). Refinement and reassessment of the SERVQUAL scale. Journal of Retailing, 67(4), 420-450.

Parasuraman, A., Zeithaml, V., \& Berry, L.L. (1994). Reassessment of expectations as a comparison standard in measuring service quality implications for future research. Journal of Marketing, 58, January, 111-24.

Parasuraman A, Zeithaml V \& Malhotra A (2005). E-S-QUAL: A multiple-item scale for assessing electronic service quality. Journal of Service Research, 7(3), 213-234.

Peng, L. Y. \& Wang, Q. (2006). Impact of relationship marketing tactics (RMTs) on switchers and stayers in a competitive service industry. Journal of Marketing Management, 22, 25-59.

Radecki, L., Wenninger, J., \& Orlow, D. (1997). Industry structure electronic delivery's potential effects on retail banking. Journal of Retail Banking Service, 19(4), 57-63.

Reinartz, W. J.. \& Kumar, V. (2003). The impact of customer relationship characteristics on profitable lifetime duration. Journal of Marketing, 67(1). 77-99.

Ravi, V., Mahil, C., \& Vidya Sagar, N. (2007). Profiling of internet banking users in india using intelligent techniques. Journal of Services Research, 6(2). 61-73.

Rowley, J., \& Dawes, J. (2000). Disloyalty A closer look at non-loyals. Journal of Consumer Marketing, 17(6), 538-549.

Rust, R.T., \& Zahorik, A.J. (1993). Customer satisfaction, customer retention and market share. Journal of Retailing, 69(2), 193-215.

Ruyter, K, Wetzels, M.., \& Kleijnen, M. (2001). Customer adoption of e-service an experimental study. International Journal of Service Industry Management, 12(2). 184-207.

Santos, F. (2003). E-service quality: A model of virtual service quality dimensions. Managing Service Quality, 13(3), 233-246.

Sheth, N. J., \& Parvatiyar, A. (1995). Relationships marketing in consumer markets Antecedents and consequences. Journal of Academy of Marketing Science, 23(4), 255-271.

Sohn, C., \& Tadisina, S.K. (2008). Development of e-service quality measure for the internet-based financial institutions. Total Quality management and Business Excellence, 19(9), 903-918.

So, H.S. (2007). An Empirical Analysis on the operational Efficiency of CRM call centers in Korea, Call center Industry Research Center.

Surjadaja, H., Ghosh, S., \& Antony, F. (2003). Determinants and assessing the determinants of eservice operation. Managing Service Quality, 13(1), 39-44.

Szymanski D \& Hise R (2000). E-satisfaction an initial examination. Journal of Retailing, 76(3), 309-322.

Tax, S. S., \& Brown, S. W. (1998a). Recovering and learning from service failures. Sloan Management Review, 40, 75-88.

Teijlingen, E. R, \& Hundley, V. (2001). The importance of pilot studies , Social research UPDATE,.35, http//sru.soc.surrey.ac.uk/SRU35.html (accessed on 16-12-2009)

Weinstein, A., \& Johnson, W. C. (1999c). Designing and delivering superior customer value concepts, cases, and applications. Boca Raton CRC Press LLC. p.119a,119b,117c,119d,124$126 \mathrm{e}, 126 \mathrm{f}, 127 \mathrm{~g}$.

Wolfinbarger, M.F., \& Gilly, M.C. (2002). comQ Dimensionalizing, Measuring and Predicting Quality of the E-tail experience, Working paper, Marketing Science Institute, Cambridge, M.A., 02-100. 
Yang, Z., \& Fang, Z, (2004). Online services quality dimension and their relationships with satisfaction a content analysis of customer reviews of securities brokerage services. The International Journal of Bank marketing, 15(3), 189-206.

Yang, Z., Peterson, R.T., \& Cai, S. (2003). Services quality dimensions of internet retailing An exploratory analysis. Journal of Services Marketing, 17(7), 685-701.

Yen, H. R. (2005). An attribute-based model of quality satisfaction for Internet self-service technology. The Service Industries Journal, 25(5), 641.

Yang, Z., \& Jun, M. (2002). Consumer perception of e-service quality from internet purchaser and non-purchaser perspectives. Journal of Business Strategies, 19(1), 19-41.

Yoo, B., \& Donthu, N. (2001). Developing a scale to measure perceived quality of an Internet shopping site (SITEQUAL). Quarterly Journal of Electronic Commerce, 2(1), 31-46

Zeithaml, V.A. (2000). Service quality, profitability and the economic worth of customers what weknow and what we need to learn. Journal of Academy of Marketing Science, 28(1), 67-85.

Zeithaml, B., \& Parasuraman, A. (1996). The behavioral consequences of service quality. Journal of Marketing, 6(2), 31-46. 